\title{
Perempuan dan Kekristenan pada Masyarakat Tolaki dan Moronene di Sulawesi Tenggara, 1915-1946
}

\author{
Basrin Melamba \\ Program Studi S1 Sejarah, Fakultas Ilmu Budaya, Universitas Halu Oleo \\ Jl. H.E.A. Mokodompit, Kampus Hijau, Bumi Tridharma, Kendari, Sulawesi Tenggara - Indonesia \\ *Alamat korespondensi: melambabasrin@uho.ac.id \\ DOI: https://doi.org/10.14710/jscl.v5i1.28089
}

Diterima/Received: 10 Agustus 2020; Direvisi/Revised: 9 Desember 2020; Disetujui/Accepted: 10 Desember 2020

\begin{abstract}
This study discusses the role of zending women or wives of European priests during the Dutch East Indies (1915-1942) in Southeast Sulawesi. The wives of zending women provide a big contribution or role for the advancement of the indigenous population. This woman is present on the stage in the religious arena by providing social services which has had a major influence on social change in society in Southeast Sulawesi. Women and zending wives act as agents and actors who assist their husbands in carrying out social service programs such as health education in the form of handling pregnant women, postpartum, care and medication, provision of sewing skills, cooking, baking and so on. This changes the lifestyle of indigenous women to be present in the public world, without forgetting their main responsibility. This research argues that zending women contribute or play a role in the advancement of the indigenous population, as well as bring about socio-cultural changes. The role of women in the stage of the religious arena by providing social services has had a major influence on the natives. The conclusion is that the role of zending women in carrying out services causes social change among indigenous Tolaki and Moronene women.
\end{abstract}

Keywords: Women; Zending; Social Changes; Tolaki and Moronene.

\section{Abstrak}

Penelitian ini membahas mengenai peranan perempuan zending atau istri para pendeta Eropa pada masa Hindia Belanda (19151942) di Sulawesi Tenggara. Perempuan istri para zending memberikan sumbangan atau peranan besar bagi kemajuan penduduk pribumi. Perempuan hadir dalam panggung arena agama dengan memberikan pelayanan sosial yang membawa pengaruh besar bagi perubahan sosial masyarakat di Sulawesi Tenggara. Perempuan istri zending berperan sebagai agen dan aktor yang mendampingi suami dalam menjalankan program pelayanan sosial, seperti penyuluhan kesehatan berupa menangani ibu hamil, nifas, perawatan dan pengobatan, pembekalan keterampilan menjahit, memasak, membuat kue, dan sebagainya. Program pelayanan sosial itu telah mengubah pola hidup perempuan pribumi untuk dapat hadir di dunia publik, tanpa melupakan tanggung jawab utama mereka. Penelitian ini berargumen bahwa perempuan zending memberikan sumbangan atau peranan bagi kemajuan penduduk pribumi, serta membawa perubahan dalam kehidupan sosial budaya. Peranan perempuan dalam panggung arena agama dengan memberikan pelayanan sosial membawa pengaruh besar bagi kalangan pribumi. Hasil penelitian menunjukkan bahwa perempuan zending dalam melaksanakan pelayanan sosial telah menyebabkan perubahan sosial di kalangan wanita pribumi Tolaki dan Moronene.

Kata Kunci: Perempuan; Zending; Perubahan Sosial; Tolaki dan Moronene.

\section{Pendahuluan}

Historiografi Indonesiasentris belum banyak menempatkan perempuan sebagai kelas kedua. Perempuan bahkan selalu dianggap sebagai makhluk lemah. Posisi penting mereka sering kali tidak tampil dalam wacana sejarah yang patriarki. Sebagian besar sejarawan kurang dapat menyadari bahwa kajian mengenai perempuan begitu menarik, sekaligus menjadi sumbangsih baru dalam kekayaan narasi historis. Ketidakmampuan melihat lebih jauh peranan mereka menyebabkan tulisan mengenai perempuan langka. Menurut Kuntowijoyo (2003) gejala tersebut adalah manifestasi penulisan sejarah yang bersifat andocentric atau hanya milik kaum laki-laki yang 
cenderung maskulin dan memiliki kekuasaan patriarkal. Pada akhirnya, lahir sejarah yang bercorak patriarki. Salah satu indikatornya adalah menggunakan materi politik yang bersifat militeristik. Dua kekuatan tersebut cenderung mengedepankan peranan laki-laki.

Seiring perkembangan historiografi, telah banyak kajian atau penelitian mengenai sejarah perempuan di Indonesia. Studi-studi tersebut dapat dijadikan sebagai rujukan dan model penulisan di berbagai daerah. Namun demikian, dalam kasus penulisan sejarah yang berfokus pada kajian mengenai wilayah Sulawesi Tenggara, perempuan belum mendapat perhatian serius. Padahal, jika membaca sumber-sumber baik lokal maupun kolonial yang ada di daerah ini, khazanah sejarah perempuan sangat menarik. Salah satu kajian yang cukup penting untuk dilihat lebih jauh adalah keberadaan istri para pendeta pada masa Hindia Belanda. Historiografi kekristenan juga belum banyak mengungkap peranan wanita (Niemeijer, 2012; Jong, 2010; Aritonang \& Steenbrink, 2008). Jika boleh disebut topik, maka topik mengenai perempuan terlalu lama diabaikan dalam historiografi lokal Sulawesi Tenggara. Apalagi, dalam topik-topik mengenai kristenisasi di suatu wilayah, pekerjaan zending sering kali hanya berpusat pada kegiatan para pendeta saja, yang notabene adalah kaum pria. Padahal, peranan istri para pendeta sangat vital. Mereka tidak hanya berperan sebagai pendukung saja, melainkan juga memainkan peranan penting dalam kristenisasi di Sulawesi Tenggara. Sumbangsih para istri pendeta itu telah memberi warna dalam kehidupan sosial masyarakat Tolaki dan Moronene yang pada gilirannya mengubah banyak hal. Keberhasilan kristenisasi di dua daerah itu, membuktikan bahwa istri para pendeta dapat dilihat sebagai agen perubahan itu sendiri, karena mereka terlibat langsung dalam upaya memberikan pelayanan sosial, seperti: kesehatan, pendidikan, dan keterampilan.

Kehidupan jemaat Kristen Protestan di Sulawesi Tenggara, jika dilihat dari berbagai sumber sejarah yang ada, terdapat beberapa nama tokoh perempuan yang juga mempunyai peranan dalam memberikan pelayanan sosial kepada penduduk pribumi di Tolaki dan Moronene. Mereka adalah Anna van der Klift (istri Ds. Hendrik van der Klift dan Jantje Biuljleveld (istri
Ds. Jacob Schuurmans). Keduanya menjadi aktor penting dalam hal pelayanan sosial di bidang pendidikan dan kesehatan. Peranan Anna dan Jantje begitu menentukan perkembangan dan kemajuan misi zending yang diemban oleh suami mereka. Lewat pendekatan yang tidak biasa, yaitu melalui kaum perempuan lokal, maka upaya modernisasi yang dilakukan para pendeta, yang juga suami mereka, dapat terlaksana dengan baik. Keterlibatan para istri pendeta guna memajukan kaum pribumi, pada dasarnya didukung dan mendapat izin dari Nederlandse Zendingsvereniging (NZV) yang mengizinkan perempuan untuk terlibat atau mengambil bagian dalam pelayanan gereja, baik sebagai petugas kesehatan, guru, maupun memberikan pelayanan. Para perempuan (pribumi) biasanya hanya menjadi jemaat biasa, tidak terlibat atau mengambil bagian dalam pelayanan pada jemaat. Mereka datang ke gereja hanya untuk mengikuti ibadah, selebihnya para kaum laki-lakilah yang lebih mendominasi dalam semua aspek pelayanan sosial di gereja. Pada titik kulminasi yang demikian itu, Anna dan Jantje tergerak untuk menggerakan para perempuan Kristen Tolaki dan Moronene. Mereka diberdayakan agar dapat berkembang dan ikut ambil bagian dalam proses kristenisasi.

Tanpa disadari, keterlibatan perempuan Tolaki dan Moronen ini menyebabkan terjadinya perjumpaan kebudayaan dari dua entitas yang berbeda, sehingga melahirkan dinamika perubahan yang cukup berarti. Menurut Niemeijer (2012, p. 18), makna atau konteks sosial budaya yang terkait dengan penasranian belum banyak mendapat perhatian para peneliti. Oleh karena itu, sudah seyogyanya untuk melakukan pembaharuan historiografi terhadap sejarah gereja Indonesia yang memasukkan aspek-aspek politik, budaya, dan sosial. Abad XIX merupakan periode sejarah yang dipenuhi dengan laki-laki sebagai aktor, sedangkan perempuan tidak banyak hadir dalam sejarah Hindia Belanda. Jika dikaji secara lebih kritis, perempuan (pribumi) seperti di Tolaki dan Moronene, juga ikut terlibat dala pelayanan sosial gereja. Dengan demikian, dapat disebutkan bahwa kehadiran para isteri pendeta di Tolaki dan Moronene membuat perempuan pribumi mulai keluar dari kehidupan privatnya menuju ke ranah publik. Hal itu dapat dilihat dari dinamika 
kekeristenan di wilayah ini yang melibatkan kaum perempuan.

Oleh karena itu, berdasar pada penjelasan, terdapat beberapa persoalan yang dianalisis dalam kajian ini, yaitu peranan para wanita atau istri pendeta dalam kegiatan zending, aktor perempuan zending yang mendukung, baik secara moril maupun materiil dalam pelayanan sosial pada masa Hindia Belanda, serta melihat dampak fenomena tersebut terhadap kehidupan sosial masyarakat Tolaki dan Moronene. Kajian ini bertujuan untuk menjelaskan sejauh mana peranan perempuan atau istri para pendeta Eropa dalam mengembangkan pelayanan di kalangan baik masyarakat umum maupun jemaat di Tolaki dan Moronene. Selain itu, kajian ini juga bertujuan untuk menjelaskan siapa saja tokoh perempuan atau aktor perempuan zending yang berperan dalam pelayanan sosial pada masa Hindia Belanda, serta menjelaskan dampak peranan perempuan zending dalam kehidupan sosial masyarakat Tolaki dan Moronene.

\section{Misi Zending dan Kerja-Kerja Perempuan}

Periode atau abad zending dimulai sejak 1797 hingga 1942/1951 (Jong, 2010). Sebuah periode yang cukup panjang dan begitu berpengaruh dalam kehidupan masyarakat Indonesia. Zending tumbuh dan berkembang sejalan dengan kekuasaan Pemerintah Hindia Belanda di Indonesia. Pada awalnya, misi zending berlangsung di Jawa, disusul Sumatera dan Kalimantan (Aritonang \& Steenbrink, 2008). Setelah misi zending mulai mapan di Jawa, mereka mulai masuk ke Sulawesi, seperti: Manado, Tana Toraja, serta Poso. Dalam beberapa sumber dikabarkan bahwa terdapat banyak orang, baik laki-laki maupun perempuan yang ikut terlibat dan dipercaya untuk melakukan kegiatan perkabaran Injil di suatu tempat (Randwijk, 1989, p. 7). Sebagai contoh Ido Enklaar. Dalam karyanya yang berjudul Agnenieta van der Veer, disebutkan bahwa meskipun secara resmi ia bertugas pada Nederlands Zendeling Genootschap (NZG) dan menerima suatu perintah khusus (1826) sebagai kemandirian besar, namun Enklaar banyak mencurahkan perhatian pada perjalanan dan petualangan selama dua setengah tahun mendampingi suaminya, yaitu
Willem Luyke di Leti. Enklaar menggambarkan keingintahuan dan mencurahkan beberapa kata pada karyanya sebagai seorang pendeta perempuan.

Hampir seratus tahun kemudian, hadir Pendeta Ds. Hendrik van der Klift yang melakukan perkabaran Injil bagi orang Tolaki dan Moronene di Sulawesi Tenggara. Pendeta Klift tidak berjalan sendirian. Sang istri juga ikut mengambil peranan sosial dalam kegiatan keagamaan, baik di gereja maupun di tengah masyarakat dua suku tersebut. Klift dan istrinya melakukan hal itu selama tiga puluh tahun, yakni pada 1916 sampai dengan 1946. Usaha yang dilakukan oleh Ds. Hendrik van der Klift antara lain memberikan pelayanan kesehatan, pendidikan, dan pembelajaran keterampilan. Pada saat tertentu, ia melakukan perjalanan menjelajahi wilayah untuk memetakan kehidupan Suku Tolaki dan Moronene, sekaligus mengunjungi pemukiman-pemukiman penduduk. Peranana Ds. Hendrik van der Klift yang lain adalah mendatangkan pendeta-pendeta dari Belanda, dan negara-negara Eropa lain. Para pendeta yang dihadirkan pada gilirannya telah mampu bertindak sebagai the important determinant di kehidupan sosial masyarakat. Di tengah pelayanan dan perubahan yang dilakukan para pendeta tersebut, terdapat peranan kaum perempuan zending (istri para pendeta). Mereka telah turut membantu dalam memberikan pelayanan kepada pribumi, khususnya perempuan.

Wilayah kerja Ds. Hendrik van der Klift dan Anna van der Klift-Snijder adalah semenanjung tenggara pulau Sulawesi (Het Vaderland: staatenletterkundignieuwsblad, 8 April 1933). Wilayah itu masih asing bagi banyak orang, khususnya para pejabat kolonial di Batavia, karena kondisinya yang masih terisolir di tengah hutan yang lebat dan jauh dari tepi pantai. Wilayah semenanjung selatan Sulawesi itu baru mulai dikenal pada awal abad XX, meskipun sebenarnya, daerah ini telah dikunjungi oleh beberapa pelancong di masa lalu. Lewat laporan perjalanan para penjelajah, keberadaan wilayah pedalaman semenanjung selatan Sulawesi mulai diketahui. Oleh karena laporan-laporan dari para petualang sangat terbatas, maka van der Klift dan istrinya dapat disebut sebagai perintis (Muller, 1955, p. vi; Lindenborn, 1925, p. 4; Pingak, 1963; Jongeling, 1976). 
Ketika cuti di negeri Belanda, para istri pendeta biasanya memberikan ceramah dan berhasil mengumpulkan dana bagi kerja-kerja mereka di Sulawesi Tenggara. Mereka melakukan tugasnya secara diam-diam, namun tetap dengan penuh tanggung jawab. Pekerjaan itu kebanyakan terbatas pada tugas yang saat itu dianggap sebagai khas wanita, seperti: penyuluhan di bidang kesehatan, pekerjaan tangan (keterampilan menjahit, membuat kue, dan membuat anyaman), pelajaran membaca di luar sekolah, serta merawat bayi dan anak-anak. Secara singkat, dapat dikatakan bahwa mereka berusaha untuk membentuk gadis dan perempuan menjadi istri dan ibu yang baik dalam rumah tangga menurut ajaran Injil. Kegiatan tersebut kemudian dijalankan pula oleh sebuah Yayasan bernama De Vrouwen Zendings Bond (VZB) atau Perserikatan Wanita Zending (PWZ) yang didirikan di negeri Belanda pada 1929 (Muller, 1955, p. 2).

Sumbangan nyata para istri pendeta ini terlihat pada upaya mencegah kematian bayi dan anak di Sulawesi Tenggara pada masa kolonial. Perempuan Tolaki dan Moronene dilatih untuk memproduksi sandang dan pangannya sendiri dengan memanfaatkan hasil alam di sekitar mereka. Anna van der Klift-Snijder dan suaminya melatih masyarakat Tolaki dan Moronene agar mereka dapat terbebas dari orang Bugis dan para pedagang asing lain yang telah tinggal di sejumlah pulau dan pantai tenggara Pulau Sulawesi. Para pedagang inilah yang menguasai perekonomian dan perdagangan pakaian dan kain katun serta material lain (Klift-Snijder, 1925; Klift-Snijder, 1933). Para perempuan zending ikut membantu dalam hal emansipasi sosial dan ekonomi jemaat Kristen yang baru. Mereka memberi bantuan dan uang untuk mengisi kebutuhan rumah-rumah sakit atau poliklinik dan wisma milik zending, seperti kain tekstil, untuk perayaan natal dan perlengkapan zending. NZG juga melihat bahwa keberhasilan misi zending ini juga ditentukan oleh keikutsertaan kaum perempuan. Oleh karena itu, para perempuan zending sangat penting perananya dalam situasi yang demikian. Mereka diyakini telah mampu memahami alam berpikir kaum perempuan. Para perempuan zending membekali diri dengan belajar bahasa daerah dan adat istiadat masyarakat Tolaki dan Moronene di Sulawesi Tenggara.
Pendeta Klift berangkat bersama istrinya dan Petroes Wongga ke Mowewe pada akhir 1916. Perjalanan itu ditempuh dengan menggunakan kuda gunan. Mereka mengunjungi mengunjungi tiga kampung, yaitu: Lalo'eha, Walasingi, dan Lambo (van der Klift, 1922, p. 41; Wongga, 2006, p. 29). Kedatangan mereka diterima dengan baik oleh masyarakat di ketiga kampung tersebut, sehingga pada akhirnya terbentuk komunitas Kristen awal di kalangan Orang Moronene. Enam tahun kemudian, jumlah orang Kristen berkembang pesat, yakni berjumlah 548 jiwa di Mowewe dan 216 jiwa di Sanggona (van der Klift, 1922, p. 142). Tujuan utama Klift dan istrinya adalah mengkristenkan Kapala Kambo (Kepala Kampung Mowewe) yang bernama Kiloo. Selain itu, mereka juga berusaha mengkristenkan dua orang To'noomotuo (tetua atau kepala adat) yang juga seorang "anakia" (bangsawan) dalam masyarakat Mowewe, yakni Korahi dan Ta Beke. Setelah dibaptis, mereka menggunakan nama baptis mereka, yaitu Hendrik Ta'olo untuk Korahi dan Johannes Po'emba untuk Ta Beke. Begitu pula dengan istri dari ketiga tokoh masyarakat Mowewe itu. Seorang Tolea, pendeta urusan perkawinan dalam masyarakat Mowewe, yang bernama Waniha juga ikut dibaptis (Suddin Tonga, wawancara, 27 Oktober, 2017). Adapun istri van der Klift juga berperan dalam upaya tersebut. Ia dikabarkan mendekati para perempuan pribumi di wilayah Mowewe dan Sanggona.

Kristenisasi pada masa awal ini juga dibantu oleh para pemuda yang datang dari Minahasa dan Sangir (Sulawesi Utara), serta Ambon. Mereka datang sebagai guru di sekolah-sekolah pemerintah kolonial. Semuanya diterima baik oleh masyarakat, dan banyak yang menikah dengan putri-putri keluarga tokoh masyarakat dan keluarga "anakia". Istri para guru zending tersebut dihormati oleh masyarakat luas, mereka dipanggil "nyonya" (ignora bahasa Portugis artinya nyonya, sedangkan panggilan "nyonya" hanya ditunjukkan kepada istri Pendeta Belanda yang dianggatp elite agama) (Melamba, 2017). Selain para pemuda tersebut, ada juga seorang perempuan dari Suku Moronene yang rajin melakukan kunjungan ke rumah-rumah untuk mengajarkan cara-cara menolong orang bersalin. Dia adalah istri Saripa. Pada awalnya, usaha dari istri Saripa ini banyak mengalami hambatan dari dukun-dukun kampung. Walaupun 
demikian, usaha ini perlahan menemui titik terang, ketika para perempuan yang hendak bersalin meminta pertolongan kepada istri Saripa atau mereka yang pernah belajar cara-cara membantu persalinan. Perlahan-lahan, istri Saripa semakin dipercaya oleh masyarakat (Paulus, 1989, p. 56; Limba et al., 2014). Saripa dan sang istri biasanya menyuguhkan kue kepada tamu yang datang ke rumah mereka guna mendengarkan cerita-cerita keagamaan. Penyuguhan kue-kue secara demikian sudah menjadi kebiasaan dalam perkumpulan Kristen di Taubonto (Nusriani, 1999, p. 49; Limba et al., 2014, p. 298).

Masuknya orang Kristen telah membawa pengaruh dalam hal keterampilan atau skill, seperti pertukangan kayu atau membuat rumah (tuka mbatu), menjahit (mose'u), membuat kue, merawat bayi, keterampilan melukuatau mengolah sawah (megalu), dan sebagainya. Zending juga membangun infrastruktur di antaranya: rumah sobat laika soba, rumah pesangrahan, rumah pertemuan baruga, sumur, jamban, rumah ibadah (gereja), fasilitas sekolah, dan sebagainya. Mereka menggunakan tenaga terampil hasil dari kaderisasi pertukangan.

\section{Peranan Anna van der Klift-Snijder, 1915-1942}

Misi zending tentu melibatkan banyak orang. Tidak hanya seorang pendeta yang menjadi sumbu gerak dari upaya tersebut, melainkan ada peranan agency dan actor dalam melaksanakan perubahan sosial. Hal ini terkait dengan pendapat Davis (1984), bahwa "aktor-aktor agama memiliki kesamaan kapasitas dengan apa yang dimiliki para agen modernisasi. Para aktor agama memiliki kemampuan untuk membuat gerakan dan tumbuh layaknya agen modernisasi" (Turner, 2006, p. 83). Kristenisasi pada masyarakat Suku Tolaki dan Moronene di Suawesi Tenggara dapat berlangsung dengan baik, karena adanya konstribusi penting para istri pendeta yang bertugas di wilayah tersebut. Dengan demikian, tidak hanya para pendeta melainkan juga istri pendeta sangat memiliki andil dalam perkabaran Injil dan perkembangan masyarakat Kristen di kedua wilayah itu.

Kampung Mowewe adalah pusat sekaligus titik awal kekristenan di Sulawesi Tenggara.
Kampung ini oleh Hendrik van der Klift dijadikan pusat pertama perkabaran Injil. Van der Klift berhasil mendirikan gereja pertama di Kampung Mowewe. Van der Klift dan istrinya bisa disebut sebagai perintis (Muller, 1955, p. vi; Lindenborn, 1925, p. 4; Pingak, 1963; Jongeling, 1976; Lawole \& Sonaru, 1982). Sebagai seorang perempuan, Anna membangun relasi yang baik dengan para perempuan zending lain yang bekerja di lapangan zending. Ia juga membangun kedekatan emosional dengan para perempuan Kristen di Mowewe dan sekitarnya, termasuk kaum pria. Anna juga membantu suaminya dalam meletakkan dasardasar pelayanan kesehatan dan pendidikan modern bagi masyarakat. Hal itu dilakukan antara lain karena saat itu masyarakat masih melakukan praktik pengobatan tradisional seperti perdukunan dan ilmu gaib (Jong, 1976; Jubelium 100 tahun Injil di Sulawesi Tenggara: 1916-2016, 2016, p. 3).

Sebelum 1930, tidak banyak perempuan yang terlibat dalam kegiatan sosial di bidang kesehatan. Padahal, pada 1920-an, terbentuk sebuah panitia yang merumuskan kerja-kerja sosial di kalangan kaum perempuan dan gadis. Mereka kemudian berkirim surat berisi pertanyaan kepada para pendeta mengenai kemungkinan melakukan dan cara berkonstribusi dalam kerja-kerja sosial. Pelayanan sosial ini terlepas dari pelajaran kerajinan tangan yang diajarkan oleh para istri pendeta kepada kaum perempuan dan gadis kampung. Di antara banyaknya perempuan, Anna van der Klift merupakan salah seorang (mungkin yang pertama) yang berpikir tentang pelayanan bidang kesehatan kepada para perempuan kampung. Dasar berpikir Anna waktu itu adalah kondisi kesehatan masyarakat yang begitu buruk. Selain itu, angka kematian bayi juga cukup tinggi. Persoalan ini diduga berasal dari kepercayaan takhayul dan ketidaktahuan para ibu terhadap problematika kehamilan dan persalinan (Jong, 2010a, p. 146).

Setelah kembali dari cuti pada 1934, Anna memulai pelajaran kerajinan tangan dan kesehatan di Kampung Mowewe bagi para perempuan wanita dan gadis muda. Tujuannya ada tiga, yaitu membentuk kelompok atau tim yang bertugas sebagai bidan; mempersiapkan mereka untuk menjadi ibu yang dapat merawat bayi-bayinya, sekaligus untuk menekan angka kematian bayi di 
Kampung Mowewe; serta berusaha mengurangi ketergantungan penduduk pada para penjahit Cina dan Bugis melalui pemberian pelajaran keterampilan tangan. Tujuan lain adalah agar penduduk lebih terbuka menerima model kesehatan Barat. Anna bersama guru Pither J. Rumono membuka kelas dan mengatur kursus kesehatan ibu serta perawatan bayi dan anak di Mowewe. Ketika tidak sedang mengajar di Kampung Mowewe, ia melakukan perjalanan ke kampung-kampung lain yang berada di wilayah Mowewe.

Kegiatan tersebut ternyata juga mendapat dukungan dari Pemerintah Kolonial Belanda. Selain itu, penguasa Swapraja Luwu, wilayah Afdeeling Luwujuga ikut memberikan sumbangan. Besaran sumbangan dan subsidi tidak diketahui. Kapita Kolaka, Pu'uwatu Ra'eyati, juga mendukung kegiatan tersebut. Kegiatan tersebut mendapat dukungan dari banyak pihak, walaupun diyakini berisi muatan politik, seperti ketika Kapita Kolaka mendorong van der Klift membuka sekolah dan menawarkan pemungutan uang sekolah (Jong, 2010a, p. 96).

Kursus yang diusahakan oleh Anna van der Klift juga digunakan sebagai bahan les dalam pendidikan rakyat, baik dari pemerintah maupun zending, dan muncul dalam bentuk tercetak, yang diterjemahkan dalam bahasa Melayu oleh Victor Rumagit. Versi Melayu yang berjudul Tolonglah Dirimoe Sendiri dicetak di Batavia dan Belanda. Sementara itu, versi dalam bahasa Tolaki (Tomekongga) dicetak di Mowewe.

Oleh karena dianggap sebagai bagian tidak terpisahkan dari karya zending, karya Anna van der Klift juga mendapatkan dukungan dari pemerintah di Negeri Belanda. Selama cuti pada 1933 dan 1934, Anna van der Klift mendapatkan bantuan buku pelajaran serta materi kerajinan dari Organisasi Gadis Muda Rotterdam Kaasihan Goesti, kenalan sahabat zending di Belanda dan Jawa, dan sejumlah wartawan.

\section{Peranan Jantje Schuurmans dalam Pelayanan Sosial, 1922-1946}

Jantje Schuurmans memiliki nama asli Jantje Biuljleveld. Ketika ia menikah dengan Pendeta Jacob Schuurmans, nama belakangnya berubah mengikuti nama belakang suaminya. Mereka menetap dan bertugas di Lambuia yang termasuk dalam wilayah Onderafdeeling Kendari. Jantje Biuljleveld lahir di Winsum, pada 10 Februari 1898. Ia wafat di Soest, pada 4 Oktober 1973.

Jantje Schuurmans adalah saudara kandung Jan Bijleveld yang atas nama Utrech Zending Verenigeeng (UZV) menjadi kepala sekolah pertukangan di Morotai Maluku Utara (19181931). Sejak 1931 sampai dengan 1934, Jan menjadi guru zending sekaligus kepala perkebunan kelapa Wari di Tobelo Halmahera wilayah Maluku Utara. Ia meninggal pada 1934 di Tobelo, Maluku Utara.

Jantje Schuurmans sendiri mengajarkan kepada penduduk cara membuat kue, roti, kursus menjahit, dan mengenalkan mentega di Kampung Lambuia (Bachruddin, wawancara, 24 November, 2017). Selain itu, ia dan para perempuan zending lainnya dari perkebunan kopi di Sulawesi Tenggara juga memperkenalkan tradisi minum kopi. Jantje juga mengenalkan sabun mandi sebagai pengganti kayu wilalo (sabun mandi yang biasanya digunakan penduduk Lambuia). Kegiatan lainnya adalah menyediakan mesin jahit bagi ibu-ibu atau kelompok jemaat binaan gereja, memanfaatkan pekarangan rumah untuk ditanami jenis tanaman bermanfaat, memperkenalkan alat musik modern seperti drum band, terompet, bass, dan lain-lain (Jongeling, 1976; Boonde, 1982; Jubelium 70 tahun Injil di Sulawesi Tenggara, 1986; Jubelium 100 tahun Injil di Sulawesi Tenggara: 1916-2016, 2016, p. 6). Dengan demikian, perubahan suatu lingkungan dapat pula diiringi perubahan kebudayaan dan perubahan kebudayaan dapat pula terjadi karena mekanisme lain, seperti penemuan baru atau invention, difusi, dan akulturasi (Poerwanto, 2010, p. 139). Selain menolong persalinan dan nifas perempuan-perempuan, mereka juga membekali para perempuan dengan keterampilan merawat bayi dengan baik dan benar. Kematian bayi dapat terjadi karena salah penanganan. Oleh sebab itu, mereka mengajarkan kepada para perempuan lokal agar bayi tidak kedinginan dan cara memotong tali pusat (plasanta) atau towuni (bahasa Tolaki) seperti pada Gambar 1.

Tercatat sejak 1923 hingga 1939, Schuurmans dan istrinya ditempatkan di Lambuia Onderafdeeling Kendari. Mereka telah berhasil melaksanakan pelayanan sosial yang dilaksanakan secara bersamaan. Mereka berhasil mendirikan 
delapan Sekolah Dasar yang termasuk dalam Zending School dan membuka sebuah poliklinik. Hal yang tidak kalah penting adalah membentuk beberapa sidang jemaat antara lain di Kampung Lambuia, Uepai, Puriala, Wolasi, Wawolemo, Roraya, dan Benua. Pada perkembangan selanjutnya, terbentuk pula kelompok jemaat di Kampung Belalo, Asao, Lamokuni, Parauna, Konawe, Hudoa, Nohu-Nohu, Pondidaha, Amesiu, Sabulakoa, Mowila, Lamooso, Tanggobu, Tatengguluri, Buke, Puduria, Lalobao, Laonti (sekarang Lakara), dan Kolono (Jongeling, 1976).

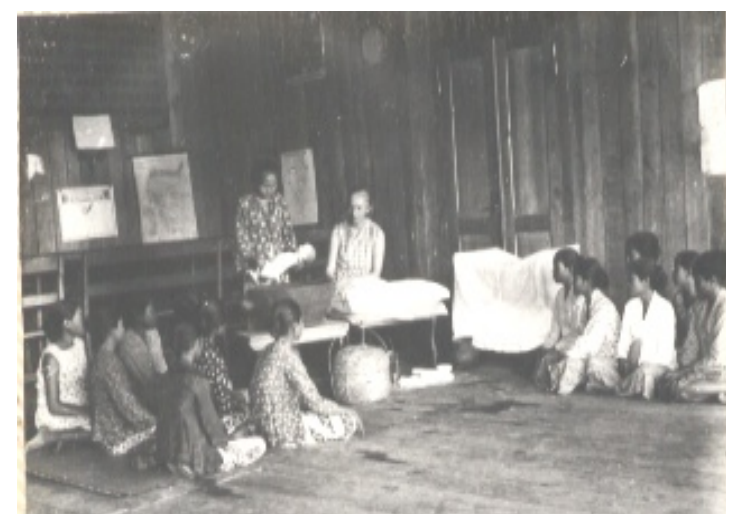

Gambar 1. Para Ibu-Ibu sedang Mengikuti Pelatihan Perawatan Bayi.

Sumber: Koleksi Gereja HervormdBelanda (NHK) dan Koleksi Kantor Sinode Gereja Protestan di Sulawesi Tenggara (Gepsultra).

Kedua penginjil, baik van der Klift maupun Schuurmans merupakan pendeta yang cukup gigih dalam pengembangan Kristen di Tolaki. Dalam sebuah laporan, van der Klift menjelaskan bahwa kesuksesan mereka dalam menyebarkan agama tidak lepas dari peranan para perempuan zending. Mereka terbukti berhasil mendekati kalangan pribumi. Sebagai seorang pendeta, mereka selalu berinteraksi secara intensif dengan kepala suku atau elite tradisional, tokoh adat (pangga sara), dan masyarakat umum untuk mengetahui kebiasaan dan karakter masyarakat lokal dengan baik. Kesuksesan kedua pendeta itu tidak lepas dari kontribusi istri mereka untuk mengubah kebiasan perempuan di wilayah zending itu.

\section{Wanita Zending dan Perubahan Sosial, 1915- 1942}

Kehadiran Kristen telah membawa perubahan di berbagai aspek yang merupakan implikasi dari invensi. Hal itu sesuai dengan pendapat Horton (1999, p. 211-216) yang menganggap bahwa terdapat beberapa mekanisme proses perubahan sosial, yaitu penemuan, invensi, dan difusi. Pengenalan keterampilan menjahit dan beberapa keterampilan lain sudah mencapai tahap difusi. Kehadiran Kristen telah memberikan pengetahuan. Pada masa lalu, perempuan Suku Tolaki dan Moronene hanya mengenal pakaian yang terbuat dari kulit kayu. Pada perkembangan berikutnya, mereka mengenal pembuatan pakaian dengan sistem pemintal tradisional yang disebut humoru. Para perempuan zending kemudian memperkenalkan kain atau arataa dan sekaligus mengajarkan teknik menjahit, serta membuat pola pakaian seperti pada Gambar 2.

Dari kegiatan itu, masyarakat mulai merasakan suatu banyak perubahan dalam diri mereka (Wongga, 2006, p. 38). Dalam penanganan Anna van der Klift pula keterampilan menjahit masuk dalam pembelajaran di sekolah formal seperti pada Gambar 3. Selain dalam pendidikan formal yang dikembangkan oleh van der Klift, ia juga memberikan pendidikan nonformal seperti pada Gambar 4 (Wongga, 2006, p. 43).

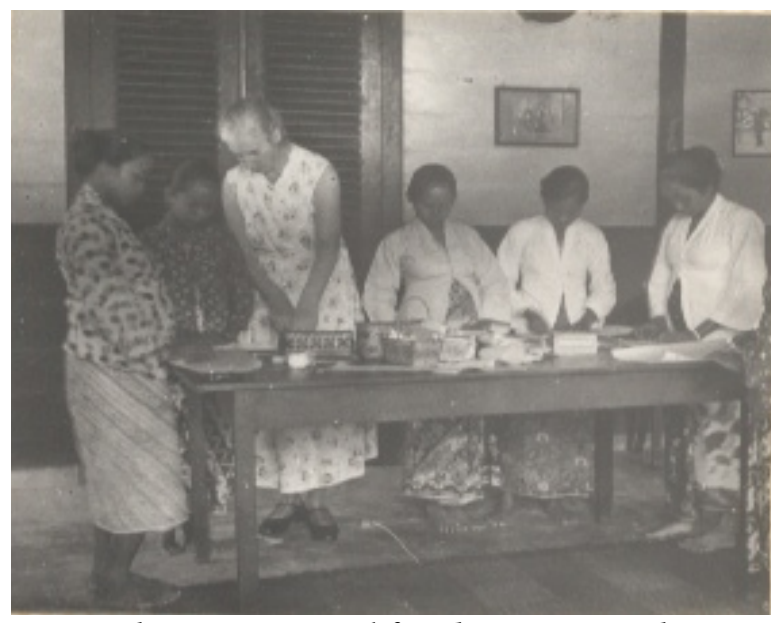

Gambar 2. Nyonya Klift sedang Mengajarkan Membuat Pola Pakaian.

Sumber: Koleksi NHK dan Koleksi Kantor Sinode Gepsultra.

Peranan Anna van der Klift dalam menangani kasus ibu dilakukan pada pagi hari. Setelah melengkapi dan menyempurnakan Bahasa Belanda dengan cermat, ia membagi mata pelajaran menjadi tujuh belas yang meliputi, mencegah kematian anak dan kebutuhan pendidikan dalam merawat anak; kehamilan dan 
gaya hidup perempuan hamil; persiapan kelahiran dan tugas kedua orang tua; tempat tidur ibu, box bayi dan gerbang ari; kelahiran dan mandi pertama untuk bayu; cara memandikan bayi; mengapa bayi menangis; menyusui rutin dan tidak rutin; peralihan dari menyusui ke bubur nasi; persiapan bagi pelajaran memasak; memasak; penyakit anakanak dan perawatannya; masih tentang penyakit anak; pemeriksaan sementara atau penanganan awal penyakit pada anak; pesta panen (sejenis ujian); pelajaran menggunting; serta pengasuhan dan pendidikan anak-anak dewasa (Muller, 1955, p. 52).

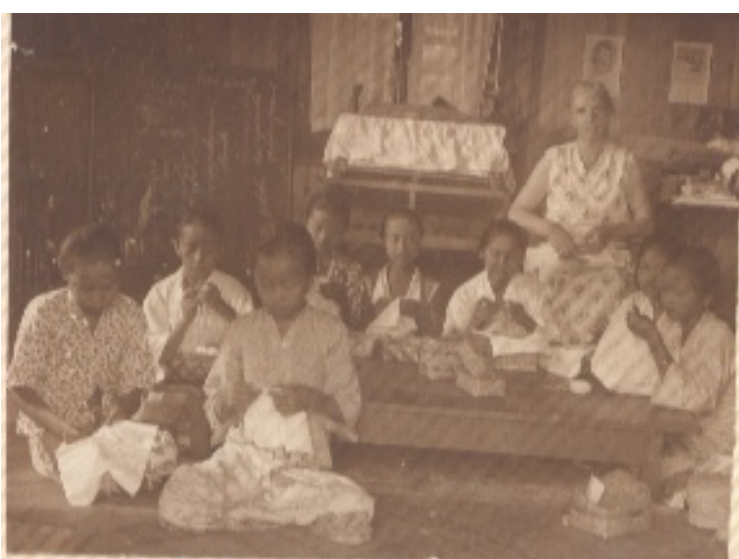

Gambar 3. Suasana Pembelajaran Menjahit Moseu pada Anak Perempuan Pribumi.

Sumber: Koleksi NHK dan Kantor Sinode Gepsultra.

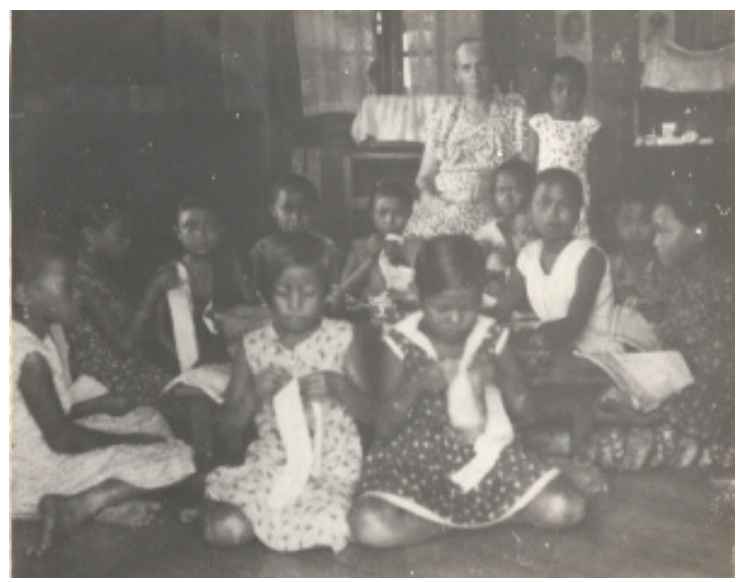

Gambar 4. Pelatihan Menjahit kepada Anak-Anak Pribumi.

Sumber: Koleksi NHK dan Koleksi Kantor Sinode Gepsultra.

Selain itu, terdapat pula pendidikan kursus bagi perempuan, gadis, dan laki-laki. Namun demikian, karena kesulitan dalam berbahasa, maka semua itu diterjemahkan dalam Bahasa Melayu sederhana (Muller, 1955, p. 53). Mereka juga dilatih keterampilan menjahit. Untuk mendukung pembelajaran para ibu, diberikan bantuan berupa mesin jahit merek Bowmen (Bachruddin., wawancara, 24 November, 2017). Mereka juga memberikan bantuan mesin jahit kepada keluarga Muslim.

Para perempuan zending ini juga memperkenalkan bahan pakaian berupa kain, dan bahkan memberikan bantuan secara gratis berupa baju, sarung, dan celana. Pihak zending telah menyediakan peralatan atau kebutuhan menjahit secara gratis, seperti: benang, jarum, termasuk kain yang menjadi bahan baku dalam menjahit. Selain itu, mereka juga memperkenalkan sampo dan peralatan dapur dari Eropa. Ada cara unik untuk mendekati anak-anak pribumi, yaitu memberikan cermin serta kelereng (Jong, 2010a, p. 3). Permainan menyerupai kelereng (baguli) sebenarnya sudah di kenal anak-anak Tolaki, tetapi mereka masih menggunakan bahan dari batu alami. Sementara itu, kelereng yang diperkenalkan zending terbuat dari kaca. Mereka tentu sangat senang mendapatkan permainan baru yang terlihat canggih.

Masyarakat Tolaki sebenarnya juga sudah lama mengenal sabun dan sampo tradisional dari bahan alami kayu wilalo. Begitu pula dengan peralatan dapur yang terbuat dari bahan alami. Baru ketika orang Kristen Eropa datang, mereka mulai mengenal alat-alat dapur dari aluminium (Horton, 1999, p. 212).

Menurut Boonde (1982), Schuurmans sempat mengganti peralatan rumah tangga yang sebelumnya dibawa dari Eropa dengan peralatan tradisional sebagai bentuk penghargaan terhadap kebudayaan Tolaki. Adapun peralatan yang mereka bawa dari Eropa diberikan kepada penduduk Lambuia. Selain mengenal alat dapur dari alumunium, penduduk juga mengenal barangbarang baru lain. Dijelaskan oleh Klift bahwa perlengkapan yang terdiri atas kaleng susu yang diawetkan, kaleng sayuran, daging asap, biskuit merek Verkade, satu karung tepung, sebungkus sabun, dan Ovomaltine (Klift, 1955, p. 26).

Pengaruh kebudayaan buka hanya sebatas pada mode pakaian saja, melainkan juga dalam aspek perhiasan pada kain aksesoris Tolaki. Sebagai contoh adalah aksesoris tabere dan kulambu. Tabere dan kulambu adalah seni desain suku Tolaki yang hidup secara turun temurun 
(Tarimana, 1993). Pada masa lalu, masyarakat Tolaki menggunakan hiasan berupa tabere, baik pada kegiatan pesta maupun kegiatan adat. Tabere adalah jenis kain yang dihiasi ornamen atau ragam hias tertentu seperti pada Gambar 5. Tabere biasanya digunakan untuk menghiasi rumah masyarakat Tolaki untuk kegiatan tertentu. Hiasan tabere umumnya digunakan di rumah, dengan motif berupa pati-patiatau ukiran/motif. Di antara motif tersebut terdapat penataulu mbaku, penesowi, pinehiku, pinetotono, pinetariwadi, pine ona-ona, dan sebagainya.

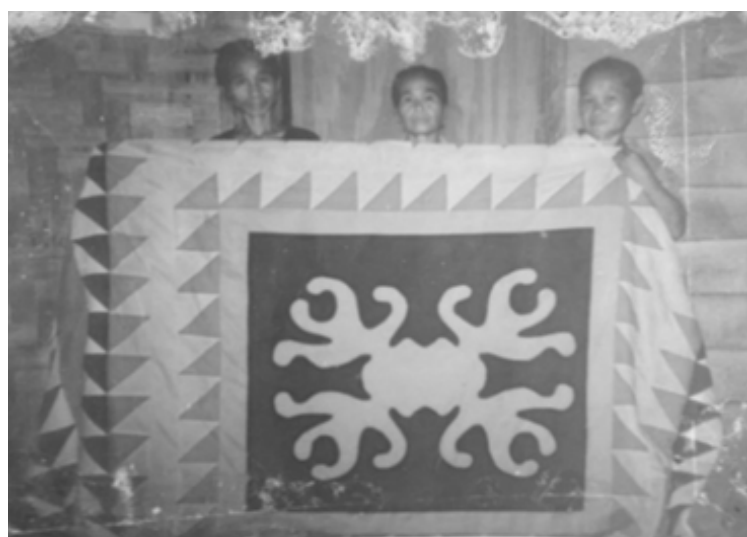

Gambar 5. Model Tabere pada Masyarakat Tolaki. Sumber: Koleksi Pendeta (Emeritus) Simon Karel.

Keterampilan membuat tabere dari kain tetap dilaksanakan oleh kaum perempuan Tolaki. Dalam membuat motif tabere, di samping menggunakan motif khas Tolaki, masyarakat juga menambahkan motif bernuasa gereja atau kekristenan. Kenyataan ini terjadi di kampung Wolasi dan beberapa kampung Kristen. Binaan Jemaat di kampung ini membuat motif tabere dengan mengadopsi model lambang salib dan Gepsultra seperti pada Gambar 6.

Para ibu-ibu biasa membuat tabere di bawah binaan seorang pendeta. Sebagai contoh adalah masyarakat Wolasi yang membuat tebere di bawah pembinaan Pendeta Simon Karel. Mereka juga membuat kerajinan anyaman terutama tikar (ambahi), ornamen berupa kain pada langit-langit (tabere), tempat sirih, dan sebagainya yang diberi ornamen hiasan berupa lukisan. Masyarakat Tolaki dapat membuat bahan pewarna sendiri dari lumpur, daun-daunan, akar-akaran, sehingga tercipta warna merah (momea), kuning (mokuni), hitam (me'eto), dan putih (mopute) (Pingak,
1963, pp. 35-47; Konggoasa, tt; Tarimana, 1993, p. 251).

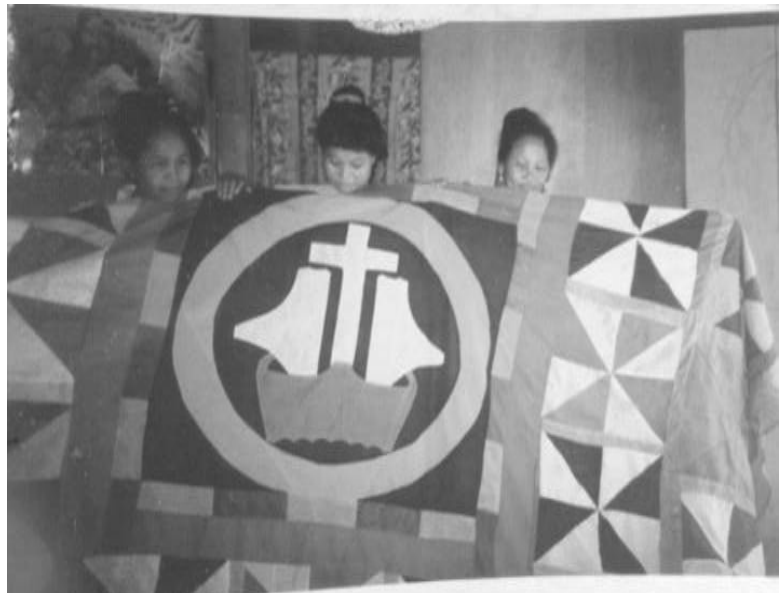

Gambar 6. Motif Tabere dengan Motif Gereja Salib, Perahu, dan Layar.

Sumber: Koleksi Pendeta Simon Karel.

Dekorasi dan perhiasan rumah kematian, yang disebut o'tenda (langit-langit), tabere (takbir), dan kulambu (tirai empat sisi dinding kamar), semuanya mengekspresikan suasana keindahan dan kemegahan rumah roh orang mati di atas kayangan (Tarimana, 1993, p. 246). Hiasanhiasan itu termasuk dalam ekspresi keagamaan jika merujuk pada pengertian seni sebagai ekspresi keagamaan menurut Koentjaraningrat (1980, pp. 395-397; Tarimana, 1993). Seni sebagai ekspresi keagamaan telah ditunjukkan oleh para ahli antropologi dalam kaitannya dengan upacaraupacara keagamaan. Sebagai contoh adalah seni rias pada tubuh manusia peserta upacara dan seni rias pada pakaian upacara yang juga menggambarkan ekspresi keagamaan (LeviStrauss, 1963; Tarimana, 1993, p. 245).

Sementara Anna van der Klift mengajar di sekolah formal dan nonformal, istri Saripa, mengadakan kunjungan ke rumah-rumah untuk mengajarkan cara-cara menolong orang bersalin. Pada awalnya, usaha dari istri Saripa ini banyak mengalami hambatan yang datang dari dukundukun kampung. Namun demikian, cara-cara yang diajarkan ternyata banyak memberikan pertolongan, maka usaha tersebut mulai lancar dan semakin banyak memperolah kepercayaan dari masyarakat (Paulus, 1989, p. 56; Limba etal., 2014, p. 298; Nusriani, 1999, p. 49). 


\section{Simpulan}

Perempuan, seperti Anna van der Klift dan Jantje Schummans, serta istri Saripa, pada dasarnya telah mewakili keberadaan perempuan Kristen pada masa kolonial Belanda. Mereka hadir ketika semangat politik etis telah mengurat dan mengakar di negeri Belanda. Mereka juga berada di atara dua situasi yang sangat penting sepanjang abad XIX hingga awal abad XX, yaitu "pasifikasi” seluruh Hindia Belanda dan adanya upaya memodernkan penduduk tanah jajahan. Pada situasi tersebut, para perempuan zending bekerja. Mungkin mereka sendiri tidak pernah tahu tujuan politik dan kebudayaan dari pekerjaan yang sedang dilakukan. Berdasar pandangan tersebut, maka keberadaan tiga orang perempuan Kristen di Tolaki dan Moronene dapat dilihat dari tiga sudut pandang, yaitu: sebagai mediator kebudayaan antara kebudayaan modern dan kebudayaan lama di Sulawesi Tenggara; sebagai penyebar semangat emansipasi kaum perempuan Tolaki dan Moronene, sehingga para perempuan di dua suku tersebut semakin berdaya untuk melawan dominasi pedagang asing yang menguasai kehidupan sosial ekonomi mereka; mereka adalah perempuan ideal yang salah satu indikatornya mampu berbuat baik untuk masyarakat (jemaat dalam pemikiran Kristen), bangsa dan agama. Itulah ke-Kristen-an yang sesungguhnya. Pada akhirnya, jika masyarakat lokal telah menjadi Kristen, maka "pasifikasi" menjadi mudah dilakukan oleh pemerintah Hindia Belanda.

\section{Ucapan Terima Kasih}

Penulis mengucapkan terima kasih kepada Fatma Saudo yang telah membaca dan mengedit teknis redaksional penulisan artikel ini.

\section{Referensi}

\section{Jubelium 70 tahun Injil di Sulawesi Tenggara.} (1986). Kendari: Sinode Gepsultra.

Jubelium 100 tahun Injil di Sulawesi Tenggara: 1916-2016. (2016). Kendari: Panitia Gepsultra.

Aritonang, J. S., \& Steenbrink, K. A. (2008). A history of Christianity in Indonesia. LeidenBoston: Brill.
Azwar, W. (2001). Matrilokal dan status perempuan dalam tradisi Bajapuik. Yogyakarta: Galang Press.

Boonde, F. N. (1982). A reflection on Christian Mission and tts prospect in the Protestant Church in South-East Sulawesi. (Tesis). Presbyterian Theological Seminary, Seoul, South Korea.

Boonde, F. N. (2016). Tapak tilas perjalanan kekristenan di bumi Sulawesi Tenggara. Kendari: Panitia Jubelium 100 tahun Gepsultra.

Davis, M. L. (1984). Lima tokoh wanita yang mengubah sejarah. Jakarta: Pustaka Jaya.

Horton, P. (1999). Pengantar sosiologi. Jakarta: Erlangga.

Jong, C. G. F. (2010). Niewe meesters, nieuwe goden: geschiedenis van de Tolaki en Moronene, Twee volkeren in Zuidoost Celebes (Indonesie) van Prehistorische tijden tot ca. 1950. Lambert Akademic Publising.

Jong, C. G. F. (2010a ). Vreemde op de kust: tet werngh van Nederlandse Zendingsvereningging in Zuidoost-Celebes (Indonesie) in de eerste helft van de twintigste eew. NUR-Omschrijving: Zending/Evangelisatie.

Jongeling (1976). Benih yang tumbuhh x suatu survey mengenai Gereja Protestan Sulawesi Tenggara (Gepsultra). Jakarta: Lembaga Penelitian dan Studi Dewan Gereja-Gereja di Indonesia.

Lindenborn (1925). Pionierswerk door zendeling $H$. van der Klifop zuid Oost Celebes. Rotterdam: MZG.

Klift, H. van. (1922). Onderzoekingstoent door zuid Kendari. Rotterdam: Orgaan Nederlandsche Zendingsvereeniging.

Klift-Snijder (1925). De ontwikkeling van het zendingswerk op Zuid-Oost-Celebes. tijdschrift voor zendingswetenschap Mededeelingen (TZM).

Klif-Snijder. (1933). De ontwikkeling van het zendingswerk op Zuid-Oost-Celebes. Tijdschrift voor Zendingswetenschap Mededeelingen $(T Z M)$.

Konggoasa. (tt). "Sulawesi Tenggara dari zaman ke zaman." (tidak diterbitkan). 
Lawole, P. dan Sonaru G. (1982). Rundu Walaka

(Gemul-Juang) Gepsultra. (tidak diterbitkkan).

Limba, R. S et al., 2014. Sejarah Peradaban Moronene. Yogyakarta: Lukita.

Melamba, B. (2017). Kebijakan Pemerintah Hindia Belanda dan Kristen Protestan di Sulawesi Tenggara (1915-1942). Dalam Sri Margana (ed.), Agama dan negara di Indonesia pergulatan pemikiran dan ketokohan. Yogyakarta: Ombak.

Muller, A. C. (1955). De memores (anak Dr. Hendrik van der Klift Pendeta pertama di Kolaka) (tidak diterbitkan).

Niemeijer, H. E. (2012). Batavia: masyarakat kolonial abad XVII. Jakarta: Masup.

Paulus, Y. A. (1989). Bertumbuh di tengah-tengah duri (Skripsi). STT Intim, Makassar, Indonesia.

Nusriani, (1999). Sejarah perkembangan Agama Kristen Protestan di Kelurahan Taubonto. Kendari: FKIP Unhalu.

Poerwanto, H. (2010). Kebudayaan dan lingkungan dalam perspektif antropologi. Yogyakarta: Pustaka Pelajar.

Pingak, Ch. (1963). Dokumentasi Kolaka. Kolaka: Pemda Kabupaten Kolaka.

Randwijk, S. C. (1989). Oegsteest: kebijaksanaan lembaga-lembaga. (tidak terbit)

Tarimana, A. (1993). Seri etnografi: kebudayaan Tolaki. Jakarta: Balai Pustaka.

Turner, Bryan S. (2006). Agama dan teori sosial. Yogyakarta: IRCiSOD.

Wongga, G. (2006). Matahilo Mowewe: suatu kajian historis-misiologis terhadap masuknya Injil di Mowewe dan maknanya bagi kehidupan jemaat dewasa ini. Makassar: STT Makassar.

Kuntowijoyo (2003). Metodologi sejarah. Yogyakarta: Tiara Wacana.

(1933, 8 April). Het Vaderland: staatenletterkundignieuwsblad. diakses dari https://www.delpher.nl/. 